\title{
Australian Journal of Teacher Education
}

\section{$1-1-2010$}

\section{The Construction Of Education as an Area of Study at Murdoch University: 1974-2003}

\author{
Di Gardiner \\ The University of Western Australia \\ Tom O'Donoghue \\ The University of Western Australia \\ Marnie O'Neill \\ The University of Western Australia
}

Follow this and additional works at: https://ro.ecu.edu.au/ajte

Part of the Education Commons

\section{Recommended Citation}

Gardiner, D., O'Donoghue, T., \& O'Neill, M. (2010). The Construction Of Education as an Area of Study at Murdoch University: 1974-2003. Australian Journal of Teacher Education, 35(6).

http://dx.doi.org/10.14221/ajte.2010v35n6.4

This Journal Article is posted at Research Online.

https://ro.ecu.edu.au/ajte/vol35/iss6/4 


\title{
The Construction Of Education as an Area of Study at Murdoch University: 1974-2003
}

\author{
Di Gardiner \\ Tom O'Donoghue \\ Marnie O'Neill \\ The University of Western Australia \\ Tom.ODonoghue@uwa.edu.au
}

\begin{abstract}
This paper is concerned with the extent to which both structural and agency factors were at play in the establishment and maintenance of an innovative model of Education Studies at Murdoch University in Western Australia, from the mid 1970s to 2003. Regarding structural factors, the fact that the University was established as one of a number of 'new' universities on the national scene, with a brief to break out of the curricular traditions of the established universities, meant that there was latitude for the adoption of new curriculum structures in outlining the parameters of Education Studies. However, it required the agency of Brian Hill, the Foundation Professor of Education, to make this happen. The paper outlines how the nature of the model that eventuated was largely a transfer of models which Hill witnessed both in North America and within Australia and which he adapted to local conditions, seeking in the process to bring about what he considered to be an improved composite version based on his professional experience in a number of universities.
\end{abstract}

\section{Introduction}

This paper provides an exposition on how Education as an area of study was constructed at Murdoch University in Western Australia between 1974 and 2003. It opens with an outline of the stimulus to engage in the study upon which the paper is based. The theoretical framing of that study is then presented. This is followed by a brief overview of the establishment of Murdoch University and the role it was expected to play as one of a number of 'new' universities on the national scene. Attention then turns to how, within the latitude offered by this new institution for adopting new curriculum structures, a model of Education as a university field of study, 'borrowed' from the US and adapted to local conditions, was coupled with a particular home-grown idea to provide a rationally developed, rigorous and innovative programme of studies. 


\section{The Stimulus for the Study}

The paper was stimulated by claims that, historically, Education as an area of study was marginalised in some universities across a range of countries, including England, the USA and Australia. Resistance appears to have emerged from opposition to locating teacher preparation, which was seen as the core of Education as an area of study, within the academy. As early as 1890, in response to a suggestion to establish a department of Education at Oxford University, "there were voices, powerful voices, within the university that spoke against any such contact with the professional training of teachers" (Pring, 1996, 122). Such opposition throughout the 1900 s led to a polarisation of views concerning the legitimacy of studies in Education within the university curriculum in other British universities (Richardson, 2002, 8) Evidence from the US suggest that the situation there was similar. For example, attempts to establish teacher preparation at Columbia University met with resistance (Reinhardt, 1954, 170) due to its tenuous position between the demands of schools for relevance and demands of the academic disciplines for substantial research (Corrigan \& Haberman, 1990, 195-211). The response by some leading US university departments of Education in their early years was to ignore teacher preparation and concentrate instead on graduate training and research (Feiman-Nemser, 1990, 211-233). However, this was a minority position and, in most cases short-lived, with Education departments eventually accepting the need to incorporate teacher preparation into their activities.

Within Australia also, various educationalists have claimed that Education, especially where it included teacher preparation, has a history of being marginalised within some of the nation's universities. For example, Bessant and Holbrook $(1995,266)$ argued in 1995, that "teacher training was never accepted at the Universities of Sydney and Melbourne in the same manner as the professional training courses such as Medicine, Law or Engineering". The suggestion was that this was a legacy of the association of teaching with the public service and apprenticeship training. Opposition to the establishment of a School of Education at La Trobe University, it has been claimed, was made on similar grounds (Bessant \& Holbrook, 1995, 266). Speaking in relation to the situation nationally in more recent times, Gill $(2004,4)$ has drawn attention to "the problem" of what she terms Education's "Cinderella status" within universities, claiming that some in the field have been made to feel like "imposters in the university sector". She has also referred to what she saw as the polarisation caused by the discrimination between those who could claim they really belonged within the university sector as a result of their research activities and those who were fully occupied teaching large classes in teacher preparation programs.

Such claims on the marginalisation of Education as a university area of study, while deserving serious attention, cannot be generalised across the Australian context, simply because a substantial corpus of research has not been developed on a university-byuniversity basis. Furthermore, while it is important that the necessary body of research be generated, it is also important to recognise that to dwell solely on it can detract researchers from investigating innovations in particular institutions which were aimed at placing Education Studies on a footing such that the field would have, and would be perceived to have, high professional status within both the academy and the community. The next section of this paper now outlines the theoretical framing of a study of one such innovation, 
reflected in the construction of Education at Murdoch University in Western Australia, between 1974 to 2003 .

\section{The Theoretical Framing of the Study}

To study how Education as an area of study has been constructed historically in any university is to engage in curriculum history. Until relatively recently, the principal focus in this field has been the school curriculum, and from the 1980s it has been addressed in a more systematic manner than hitherto, primarily influenced by the work of Goodson (1987). At the same time, there have, of late, been some developments regarding the history of the university curriculum. At a macro level, for example, Frank and Gabler (2006) investigated the shifts in emphasis in university teaching and research over the twentieth century and noted a significant redistribution away from both the humanities and natural sciences in favour of the social sciences, including studies in Education. Furthermore, they documented a change in emphasis away from basic disciplines in favour of applied disciplines (including Education), during a period when "the static separation of the ivory tower from society at large grew suspect, and the special virtues of basic or pure university knowledge lost salience" (Frank \& Gabler, 2006, 62). Specifically in relation to Education, Richardson's work investigated the internal and external forces shaping its development as an area of study in the UK and identified as significant the pressures to expand higher education provision, growing concern over the quality of secondary schools, government inquiries into teacher preparation, revision of the school curriculum and the tension between conceptual clarity and academic respectability. He claimed that such forces were able to take hold of the curriculum because "the organizing assumptions of education research and thus the conceptual underpinnings of educational studies itself remain uncertain and fragile" (Richardson, 2005, 46).

A notion underpinning the project upon which the present paper was based is that a great deal of work like that of Richardson needs to be conducted for other contexts, and across a variety of disciplines, not just Education. It was also held that such projects should proceed by conducting studies on a university-by-university basis. Hence, our focus on the five universities in Western Australia.

In our specific study on Education at one of these universities, namely, Murdoch University, we adapted Goodson's (1987) position by holding that university fields of study are sites of contestation, where different interest groups struggle for influence and power. This is a position that rejects the view of the written curriculum as a "neutral given", proposing instead that it is "a social artefact, conceived of and made for deliberate human purposes" (Goodson, 1987, 260). As such, curricula could be seen as continually changing bodies of knowledge, skills and beliefs reflecting diverse interests of sub groups and alliances which shift frequently over time. Furthermore, Goodson $(1983,4)$ asserted that the various interest groups were often in pursuit of an array of conflicting professional, ideological and political goals.

The application of Goodson's position to the historical study of curriculum provides a useful starting point for an analysis of the construction of Education as an area of study. A fundamental assertion of his is that there is a need to examine complex changes over time, rather than focusing on snapshots of unique events taking place at the present time. He 
argued that in order to develop this historical perspective, curriculum history should be studied at both the preactive and interactive level. To engage in the study of curriculum history at the preactive level is to focus on the plans, or syllabi, that outline what is included in a course, or program. This is the same as arguing that the first task should be the study of what Labaree $(1987,485)$ calls the "rhetorical curriculum", or what should be taught. It involves studying not only the structures and patterns within curriculum documents, but also identifying the various individuals and interest groups involved in their production, and the nature and extent of their influence. Our study was of this pre-active type. It is the intention to follow it up at a later stage with a study at the interactive level. This will necessitate investigating how the preactive curriculum was mediated in the classrooms. In doing so attention will be given to how the subjects or disciplines were taught, what strategies and activities were used, what experiences students had, and what learning processes took place.

\section{The Establishment of Murdoch University}

In the late 1960s and in the 1970s, a number of new universities, of which Murdoch University was one, were established in Australia, with the intention of breaking the mould of the traditional 'sandstones' (Myers, 1967). This development reflected to some extent similar developments in the US (Lombardi, 1955, 66-72) and the UK (Briggs, 1969, 95116). Regarding the US, for example, the informing assumption at that point in time was that universities are a 'public good', that investment in them serves the public interest, and that the chief beneficiary of that investment is the public itself. Concurrently, the universities became fertile grounds for cultural upheavals and radical experiments during a period which saw the beginnings of a social revolution and of political protests which sparked an alternative culture and a more liberal flavour in the curriculum .

In Australia a particular emphasis was on developing institutions that would attract a diverse range of students into interdisciplinary courses focused directly on contemporary issues (Bolton, 1985). Also, many of the new universities included in their mission a desire to make a tangible improvement to the world outside the university campus, in addition to providing excellent educational and research opportunities for their students. In this regard, Murdoch University was no exception.

Murdoch University was established under the provisions of the Murdoch University Act in 1973 and admitted undergraduate students in 1975. Up to this point there had only been one university in the State, The University of Western Australia (UWA). Throughout the late 1950s and the 1960s, demand within the community for a second university began to grow. Amongst the principal developments influencing this growth were the economic boom in the 1960s, the post-war demand for educational places for ex-servicemen, and the recommendation for increased federal funding for universities by the Murray Committee (Murray Report, 1957). In 1967, the Jackson Committee of Inquiry into Tertiary Education in Western Australia (Jackson Report, 1967) recommended that UWA be encouraged to establish a university college south of the Swan River (which bisects the city of Perth) to cater for increasing numbers of first and second year students, especially in arts and science (Bayliss, 1970, 3). At the same time, there was considerable pressure to provide a fourth veterinary school in Australia; after discussions between the State and Federal governments, Western Australia was chosen as the preferred location, with the school to be housed in the 
proposed new UWA college. As planning began, however, a change of thinking emerged, and in September 1969 the Senate of UWA advised the government that in its opinion the new institution should be autonomous from the beginning (Bayliss, 1970, 3). The decision was based on the view that full opportunity should be given to a new institution to take a fresh approach to its role (Birt Report, 1979, 45).

From the outset Murdoch University was determined to offer a very different educational experience from that offered in the older universities. The ten foundation professors were appointed in 1973, and charged with determining the nature of the new university. Vice Chancellor Stephen Griew, had "a leaning towards the new and exotic and perhaps a corresponding tendency to undervalue anything which seemed to smack of the conventional wisdom of Western Australia, particularly UWA" (Bolton, 1985, 1). The professors, however, held diverse views concerning the curriculum, ranging from a belief in academic rigour as being fundamental, to the notion of personal self-awareness as being an underlying principle (Bolton, 1985, 1). Nevertheless, they agreed that the students would be the first products of the electronic revolution and the counter culture, and that past experience of universities would not provide an appropriate blueprint for the future (Raser, 1973).

There were many critics of these ideals" (O'Brien, 1973). What neither the University's planning group nor their critics could foresee, however, was the impact of the impending economic recession which would drive students to seek specific job-related qualifications rather than pursue such an alternative view of a liberal education. This resulted in Murdoch facing strong competition from the vocationally-oriented courses offered at the Western Australian Institute of Technology and from the technical schools throughout the State. Only the schools of Veterinary Studies and Education were unaffected by the demographic trends and were able to attract a healthy intake of school leavers. Serious financial concerns were looming. By 1975, universities across the country were hit by cuts in federal funding. For a new institution, the cuts in budget had a serious impact, restricting new capital works projects and resulting in little growth over the next few years. Indeed, Murdoch had difficulty in achieving the 1,736 student enrolment it had by 1978.

After much public and destabilising debate about the viability of Murdoch University, the State Government set up a committee to enquire into its future (Williams Report, 1979). Among its recommendations was that the University should increase enrolments in the pre-service teacher education courses and introduce a teaching program for graduates, on the grounds that Education was a potential growth area. This utilitarian view, however, was not the only reason put forward for championing the maintenance and growth of Education Studies. For example, it was considered that an increase in secondary school student teachers would lead to increased numbers in other discipline areas, such as mathematics and science. Furthermore, the Committee stated that such an increase would also improve the quality of the educational life of the University by expanding opportunities for interactions between staff and students both within and outside the School of Education (Williams Report, 1979). It is arguable that thinking along these lines was influenced largely by the fact that great effort had been made from the establishment of the University's School of Education to, as it has already been put, provide a rationally developed, rigorous and innovative programme of studies. While this development was taken with the best interest of students of Education Studies and the education profession in mind, it also went a long way towards addressing the concerns of any within the University with a mind to argue against 
the area on the grounds of lack of academic rigour. Accordingly, it is apposite to consider the origins and structure of this programme which consisted of a home-grown idea being subsumed into a model of Education Studies 'borrowed' from the US and adapted to local conditions. In doing so, particular attention is given to highlighting the crucial role of the Foundation Professor of Education, Dr. Brian Hill, in this enterprise.

\section{The construction of Education as an area of study at Murdoch University}

The broad circumstances outlined so far facilitated the establishment of parameters within which a programme of Education Studies based on curriculum development principles could be developed at Murdoch University. In particular, the freedom to develop the curriculum without the constraints of an historical legacy enabled the study of Education to be constructed from first principles. A major influence on the foundation professor, Dr Brian Hill, in developing the curriculum were his experiences as a doctoral student at the University of Illinois Urbana-Champaign, although a number of "unsatisfactory" experiences in universities in Australia on his return from the US, were equally influential.

A Western Australian by birth, Hill has been judged to have been an "admirably systematic administrator, whose reputation as a Uniting Church minister did not stop him from operating tenaciously and successfully in the sometimes cut-throat world of educational politics" (Bolton, 1985, 2). In fact, he was considered one of the 'radicals' among the foundation professors (Raser, 1985, 2). Prior to this appointment he had lectured in the Faculty of Education at UWA and later, following the completion of his doctoral studies, became the foundation head of Education at the Wollongong University College, University of New South Wales.

Professor Hill completed his doctoral studies at the University of Illinois in Chicago at a time when Broudy, along with Smith and Snook, were developing within the School of Education there, their 'pragmatic' (in the Deweyian sense) model of Education Studies. Vandenberg (1992) claims that Broudy's keen interest in this area was stimulated by two questions: What is good knowledge and what is knowledge good for? In addressing these questions in relation to the construction of Education, he distinguished between two main 'types' of study within the university curriculum, namely, studies engaged in 'for their own sake' and studies engaged in by those seeking to become professionals in their field. Education he saw as belonging to the latter type, while also being a broad area of study, rather than one concerned only with the technical competencies of teaching. On this position he drew the following parallel with other professional areas of study such as architecture, engineering and education:

For a field of study to justify an autonomous existence it must

have a set of special problems that direct and focus its enquiries ... For a field of study to be professionalised it must use and organise facts and principles taken from such diverse disciplines, e.g., chemistry, physics and psychology, around the demands of its own problems ... Finally, if a field of study is to be professional, it has to utilize practice in order to illuminate theory and to use theory as a guide to practice ... A professional field of study generates rules for practice as well as principles or 
generalizations that guide practice (Broudy, Parsons, Snook \& Szoke, 1967).

Broudy then developed a schema for Educational Studies which he represented as follows:

\begin{tabular}{|l|l|l|l|l|l|}
\cline { 2 - 6 } \multicolumn{1}{c|}{} & \multicolumn{5}{c|}{ Educational Problem Areas } \\
\cline { 2 - 6 } \multicolumn{1}{c|}{} & $\begin{array}{l}\text { Aims and } \\
\text { Policy }\end{array}$ & Curriculum & $\begin{array}{l}\text { Teaching and } \\
\text { Learning }\end{array}$ & $\begin{array}{l}\text { Management } \\
\text { and } \\
\text { Administration }\end{array}$ & $\begin{array}{l}\text { Teacher } \\
\text { Preparation }\end{array}$ \\
\hline Philosophy & & & & & \\
\hline History & & & & & \\
\hline $\begin{array}{l}\text { Social } \\
\text { Sciences }\end{array}$ & & & & & \\
\hline
\end{tabular}

Figure 1: Broudy's schema for educational studies.

By identifying major educational 'problem' areas, he was equating the study of Education with the study of medicine, which draws on anatomy, physiology and psychology as relevant bodies of knowledge informing the understanding of medical problems and offering suggestions for solving them. Similarly, engineering draws on the disciplines of physics, chemistry and mathematics to develop areas of study such as chemical engineering and structural engineering. Likewise, in Education, Broudy argued, it is important to draw on philosophy, history and the social sciences to help understand educational problems and issues related to aims and policy, curriculum, teaching and learning, management and administration, and teacher preparation. In this way Education, as he saw it, is a field of study in its own right and has a research agenda just as is the case with any other area of study within the university.

The basic schema of Education Studies as outlined above should, according to Broudy and colleagues, inform the basic preparation of all educational professionals, whether they are teachers, school principals, educational administrators, regional managers, or leaders. However, they also argued that a more specific program of preparation should accompany this approach. Thus, in the case of teacher preparation, all student teachers should not only know their teaching subject(s), but should also have an education in the contributing areas of knowledge (philosophy, history and the social sciences) as they relate to that teaching subject. Furthermore, they should be engaged in the simulation of teaching and in actual teaching practice in 'real' school situations.

The organised structure, and in particular, the 'tight-coupling' between theory and practice which was evident in the Broudy model, heightened for Hill the less-thansatisfactory arrangements he perceived within Education Studies within Australia when he returned from the US. As a lecturer in Education at UWA between 1964 and 1967, he had been required to liaise with the nearby Claremont Teachers College in managing the teaching practice component of teacher preparation courses at the University. In an interview on 16 July 2007 with the present authors, he stated that he found the arrangement to be "fragmented and unsatisfactory". His subsequent experience at Wollongong University College, University of New South Wales from 1968 to 1974, where he was charged with establishing courses in Education, was, he claimed, equally troubling. Appointed at senior 
lecturer level and with a "shoestring" budget, he set about developing courses in cooperation with the local teacher's college which was located on the same campus as the University. Here he taught the theoretical aspects of education while the teacher's college staff delivered courses in methods and supervised the teaching practice. Again, he found the "disjunction between these two areas quite unsatisfactory" and was motivated to try to bridge the gap.

So keen was Hill to marry the theoretical and the practical aspects of studies in Education that he took on the task of teaching history in the History Department at Wollongong, while at the same time teaching history method and being involved in teaching practice supervision at the teacher's college. The latter experience was met with resentment from teacher's college staff, who preferred to manage the teaching practice without interference from the University. Overall, the experience from Hill's point of view contributed to the further shaping of his thinking on what would be an appropriate structure for studies in Education at university level. In 1974, he had a chance to refine his ideas when he was appointed Professor of Education at Murdoch University. He set about planning courses in the School of Education with the ideal of developing the "professional educator". Four distinct, yet interrelated, components were identified as the basis for studies in Education: Curriculum Studies, Process Studies, Professional Studies and Context Studies. Curriculum Studies focused on the subject matter to be taught (which would be attained outside the School of Education) and how to teach it (provided by the School of Education). Process Studies included such areas as child development, educational psychology and educational measurement, while Professional Studies involved field placements. Finally, Context Studies was conceptualised to bring the course to the level of "professional selfconsciousness" and set the other components into a meaningful context.

Hill commented as follows on the structure he put in place:

The way I tended to describe it (the structure) was that if we teach you the subject and how to teach it through Curriculum Studies, you become a good craftsperson. If we teach you the psychological side you become a humane craftsperson, but to become a professional educator you need to be able to see it in the context of the school in society.

The following is a diagrammatic representation of how he viewed each component as being important in each program offered in the School of Education:

\begin{tabular}{|l|l|l|l|l|}
\hline Program & Context & Process & Curriculum & $\begin{array}{l}\text { Professional } \\
\text { Practice }\end{array}$ \\
\hline Initial & & & & \\
Primary & & & & \\
Teacher Ed & & & & \\
\hline Initial & & & & \\
Secondary & & & & \\
Teacher Ed & & & & \\
\hline Tertiary \& & Adult & & & \\
Teacher Ed & & & & \\
\hline Research & & & & \\
\hline
\end{tabular}

Figure 1: Hill's schema for educational studies. 
This clearly is not a replication of Broudy's schema for the study of education. Furthermore, it is tied very much to a notion that education studies is primarily about teacher preparation at various levels (albeit recognising the importance of engaging in educational research), with little recognition that it can have a more wide-ranging role. At the same time, Hill's schema does share with Broudy the notion that programmes in education studies should not only lay out their core areas of concern, but should also make explicit the various ways in which these different areas of concern are related. In other words, it adopted a curriculumdesign approach to laying out the parameters of the field.

Hill's model remained the basis of courses in Education at Murdoch University for more than thirty years. It not only served as a foundation for the study of Education, but also acted as a guide in the appointment of staff and the organisation of administrative structures. Lecturers were appointed to work largely within one component and were required to meet regularly to monitor the development and progress of courses within it. Members of each component also had representation on the formal committees of the School of Education which managed the various programs, namely the Initial Teacher Education Committee, the Post Graduate Committee, the Research Committee, and the School of Education Board.

Further research is needed to explore in detail the nature and content of the subjects taught within the various areas delineated within this imported model adapted for local circumstances, as well as on the pedagogy adopted. Here, however, it is important to highlight that, nested within it was an approach to teaching practice which was also adapted, albeit from an Australian model. What Hill was seeking to address in this adaptation was what he had encountered at both UWA and the University of Wollongong, where the teaching practice component of teacher preparation programs was organised and managed by the affiliated teachers colleges. Under this disjointed arrangement, each student was visited by a 'supervisor' for feedback and assessment purposes, but there was little cohesion between the university program and teaching practice component. For insights into how to proceed, Hill turned to Macquarie University in New South Wales, which had been established in 1964, and which had developed interdisciplinary educational pathways. There, the 'Master Teacher in Schools' model caught his attention. Under this arrangement an individual contract was made between a teacher, who was identified as particularly competent, and a student teacher. This was an expensive model which eventually faltered for a number of reasons, including the exceptional pressure on the master teachers and the tenuous nature of the links with the University. Nevertheless, the core notion of providing school-based support for student teachers was a concept which impressed Hill.

In attempting to implement the concept of the 'master' teacher, Hill suggested that the School of Education at Murdoch should provide a staff member to support up to 15 students placed in a school for field experience. This person would be a tutor/supervisor with responsibility for teaching at the University campus and for supervising field experience. This would enable the development of a much closer association with both the mentoring teacher in the school and the student teachers, than the more traditional approach of an occasional visit from university staff during school experience. It was also felt that it would further enable connections between theory and practice to be made and to be reinforced. To achieve his vision in this regard, Hill convinced the University to fund three large caravans which would house the Murdoch University staff as they worked with students during the field placement; eventually ten were used. The purpose-built caravans 
were located at schools and provided space for students and supervisors to converse and engage in small group learning. This close monitoring of students through its tutorsupervisor program was a unique feature of initial teacher preparation at Murdoch University and indeed in Western Australia.

The robustness of Hill's model was such that no significant adaptations were made over most of the thirty-year period it was in operation. Cracks, however, began to appear in 2003. A number of circumstances contributed to this. The first of these was the discontinuation of the 'caravan approach' to teaching-practice supervision as support for the placement of large numbers of students in individual schools declined. Instead, individual staff members now had to become involved in visiting students across a much larger number of schools. This, in turn, meant that staff from the Curriculum component of teacher preparation programs became involved in professional practice supervision. Consequently, the line between the Curriculum Studies and Professional Studies components in the overall model became blurred. Furthermore, over time, tension developed between personalities involved in the four major components in the model; for the most part staff in the Context and Process component worked together collaboratively. Such cooperation, however, was not always reflected in their relationship with the Curriculum staff.

Hill's 'integrative model' for Education Studies was further weakened as the School of Education expanded and new staff modified units such that what eventuated crossed some of the boundaries between the four core areas of study. The retirement of Brian Hill, whose vision and drive had sustained the model, exacerbated the trend. Subsequent deans, with different perspectives on Education as an area of study, created certain curricular tensions. For example, a former dean, Professor David Andrich, in an interview with the present authors on 18 December 2007, stated that he felt that the Curriculum component should become central in a reformed model and that the content of the Context and Process components should be taught through the Curriculum component. Changes at the University level, which precipitated a review of the administrative structure of the School of Education, also led to a move away from Hill's model. In 2003, the Division of Social Sciences, Humanities and Education at Murdoch University was restructured and renamed the Division of Arts. Located within this new structure, the School of Education underwent internal reorganisation based on groupings of academic responsibility and administration. Overall, the outcome was that, after a near thirty-year period, the original model of Education Studies at Murdoch University had totally 'fractured' and it was no longer possible to sustain the 'tight-coupling' which had existed between theory and practice.

\section{Conclusion}

This paper on how Education was constructed at Murdoch University from the mid 1970s to the early 2000s, was stimulated, as was indicated from the outset, by claims that, historically, Education Studies was marginalised in a number of universities in the UK, the USA and Australia. Regarding the specific Australian context, however, it was also pointed out that such claims cannot be generalised across the nation since a substantial body of research has not been developed on a university-by-university basis. Furthermore, it was argued that to dwell solely on this issue can detract researchers from investigating 
innovations in particular universities which were aimed at ensuring that Education Studies would have high professional status. Murdoch University was one such institution.

The paper has indicated the extent to which both structural and agency factors were at play in the establishment of an innovative model of Education Studies at Murdoch. Regarding the former, the fact that the University was established as one of a number of 'new' universities on the national scene, with a brief to break out of the curricular traditions of the established universities, meant that there was latitude for the adoption of an approach to Education Studies which would be innovative. However, it required the agency of Brian Hill, the Foundation Professor of Education, to make this happen. The nature of the model that eventuated was largely a transfer of models which he witnessed both in North America and within Australia and which he adapted to local conditions, seeking in the process to bring about what he considered to be an improved composite version based on his professional experience in a number of universities.

While this paper should be of interest to educational historians, and especially to those who have specialised in the history of teacher preparation, it should also be instructive for those concerned about the present state of teacher education. In responding at the present time to pressures applied by funding and accrediting authorities, it is too easy to accept that current programmes of teacher preparation should be concerned only with mastering the content of one's teaching areas and associated pedagogical practices. Hill's model, implemented at Murdoch University, provides one lens for evaluating such a view. It can also provide a stimulus for suggesting ways in which initiatives can be taken to maintain the professionalization of teaching through ensuring that appropriate structures to guide programmes of initial teacher preparation are put in place.

\section{References}

Bayliss, N. S. (1970). Murdoch university planning board. Murdoch: Murdoch University. Bolton, G. (1985). It had better be a good one. The first ten years of Murdoch University. Perth: Murdoch University.

Bessant, B. \& Holbrook, A. (1995). Reflections on educational research in Australia. Victoria: AARE.

Briggs, A. (1969). Developments in higher education in the United Kingdom. In W. R. Niblett (ed). Higher education: demand and response. London: Tavistock, 95-116.

Broudy, H., Parsons, M. J., Snook, I. A. \& Szoke, R. D. (1967). Philosophy of education: An organisation of topics and selected sources. Chicago: University of Illinois.

Committee of Inquiry into Education and Training, and Employment (1979). Report of the committee of inquiry into education and training, and employment. Canberra: Australian Government Printing Service.

Committee of Inquiry into the Future of Murdoch University (1979). Report of the committee of inquiry into the future of Murdoch University. Perth: Government Printer.

Committee on Australian universities (1957). Report of the committee on Australian universities. Canberra: Commonwealth Government Printer.

Committee on Tertiary Education in Western Australia (1967). Report of the committee on tertiary education in Western Australia. Perth: UWA Press. 
Corrigan, D. \& Haberman, D. (1999). The context of teacher education. In W. R. Houston (ed), Handbook of research on teacher education. New York: MacMillan Publishing Co., 195-211.

Feiman-Nemser, S.(1999). Teacher preparation: Structural and conceptual alternatives. In W. R. Houston (ed). Handbook of research on teacher education. New York: MacMillan Publishing Co., 211-233

Frank, D. F. \& Gabler, J. (2006). Reconstructing the university: Worldwide shifts in academia in the $20^{\text {th }}$ Century. California: Stanford University Press.

Gill, J. (2004). Having our work cut out! Reflections on the Australian Association for Research in Education and the current state of Australian educational research. The Australian Education Researcher, 31, (1), 1-14.

Goodson, I. F. (1983). School subjects and curriculum change. London: Falmer Press.

Goodson, I. F. (1987). The making of curriculum: collected essays. New York: Falmer Press.

Labaree, D. F. (1987). Politics, markets and the compromised curriculum. Harvard Educational Review, 57, 483-494.

Lombardi, R. E. (1955). Universities in the USA: secondary school characteristics. Universities Quarterly, 9, 66-72.

Myers, D. M. (1967). A new university in a changing world. Melbourne: Cheshire.

Murdoch University Act 1973. Perth: Western Australia's State Law Publisher.

O'Brien, P. (1973). Unpublished speech at a meeting to discuss Murdoch University.

Pring, R. (1996). Academic respectability and professional relevance. In P. Gordon (ed). The study of education. Volume 4. London: Woburn Press, 122-136.

Richardson, W. (2002). Educational studies in the UK 1940-2002. British Journal of Educational Studies, 50 (1), 3- 56.

Raser, J. (1973). An ethos for Murdoch University, unpublished discussion paper.

Vandenberg, D. (1992). Harry Broudy and education for a democratic society. Journal of Aesthetic Education, 26, (4), 5-19. 